\title{
Leaf plasticity in successive selection cycles of 'Saracura' maize in response to periodic soil flooding
}

\author{
Thiago Corrêa de Souza(1), Paulo César Magalhães(2), Fabrício José Pereira ${ }^{(1)}$, \\ Evaristo Mauro de Castro(1) ${ }^{(1)}$ Jessé Marques da Silva Junior ${ }^{(1)}$ and Sidney Neto Parentoni(2)
}

\begin{abstract}
(1)Universidade Federal de Lavras, Departamento de Biologia, Setor de Fisiologia Vegetal, Campus Universitário, Caixa Postal 37, CEP 37200-000 Lavras, MG, Brazil. E-mail: thiagonepre@hotmail.com, fjprock@hotmail.com, emcastro@ufla.br, jesseagronomo@yahoo.com.br (2)Embrapa Milho e Sorgo, Caixa Postal 151, CEP 35701-970 Sete Lagoas, MG, Brazil. E-mail: pcesar@cnpms.embrapa.br, sidney@cnpms.embrapa.br
\end{abstract}

\begin{abstract}
The objective of this work was to assess the effect of successive selection cycles on leaf plasticity of 'Saracura' maize BRS-4154 under periodical flooding in field conditions. Soil flooding started at the six-leaf stage with the application of a 20-cm depth water layer three times a week. At flowering, samples of leaves were collected and fixed. Paradermic and transverse sections were observed under photonic microscope. Several changes were observed throughout the selection cycles, such as modifications in the number and size of the stomata, higher amount of vascular bundles and the resulting decrease of the distance between them, smaller diameter of the metaxylem, decrease of cuticle and epidermis thickness, decrease of number and size of bulliform cells, increase of phloem thickness, smaller sclerenchyma area. Therefore, the successive selection cycles of 'Saracura' maize resulted in changes in the leaf anatomy, which might be favorable to the plant's tolerance to the intermittent flooding of the soil.
\end{abstract}

Index terms: Zea mays, hypoxia, leaf anatomy, tolerance to flooding.

\section{Plasticidade foliar nos sucessivos ciclos de seleção do milho 'Saracura' em resposta ao alagamento intermitente do solo}

Resumo - O objetivo deste trabalho foi avaliar o efeito de sucessivos ciclos de seleção na plasticidade foliar do milho 'Saracura' BRS-4154 sob alagamento intermitente do solo em condições de campo. O alagamento do solo iniciou-se no estádio de seis folhas com a aplicação de uma lâmina de $20 \mathrm{~cm}$ de água três vezes por semana. No florescimento, foram coletadas e fixadas amostras das folhas. Secções paradérmicas e transversais de amostras foram observadas em microscópio fotônico. Várias modificações foram observadas durante os ciclos de seleção, como o número e o tamanho dos estômatos, a maior quantidade de feixes vasculares e a consequente diminuição da distância entre eles, o metaxilema com diâmetros menores, a diminuição da espessura da cutícula e da epiderme, a diminuição no número e tamanho das células buliformes, o aumento da espessura do floema e a menor área de esclerênquima. Os sucessivos ciclos de seleção do milho 'Saracura', portanto, levaram a mudanças na anatomia foliar, as quais podem ser favoráveis à tolerância da planta ao alagamento intermitente do solo.

Termos para indexação: Zea mays, hipoxia, anatomia foliar, tolerância ao alagamento.

\section{Introduction}

The excess of water in the soil can lead to dramatic consequences in the process of gas diffusion. Since gases diffuse 10,000 times faster in the air than in the water, an impoverishment of oxygen availability (hypoxia) results both in the soil and in the plant parts (Dat et al., 2004). Under oxygen restriction, the tricarboxylic acid cycle is interrupted due to the absence of reducing power, and the anaerobic metabolism is activated (Sairam et al., 2008).
This situation can be found in flooded soils. However, more attention has been directed to the adaptative mechanisms of roots rather than to that of leaves (Bragina et al., 2004). Up to this moment, few studies have shown leaf modifications due to root flooding. Nonetheless, some morphological (Huber et al., 2009) and anatomical (Stoyanova et al., 2002; Yordanova et al., 2005) alterations have been found. Comparatively, evidences of leaf plasticity are more known in completely flooded plants. Physiological

Pesq. agropec. bras., Brasília, v.45, n.1, p.16-24, jan. 2010 
as well as anatomical alterations have been observed in those plants, which are also known as amphibious plants (Voesenek et al., 2006; Mommer et al., 2007).

Plasticity can be defined as the ability of plants to adjust their performance through morphological or physiological modification in response to environment variation (Navas \& Garnier, 2002). Although maize (Zea mays L.) can be sensitive to flooding, it possesses considerable genetic variability to tolerance (Zaidi et al., 2007), and can expressively respond to these conditions with the plasticity of its organs.

The inability of the maize crop to respond well to the low availability of oxygen in the rhizosphere caused by root flooding results in substantial losses in productivity (Zaidi et al., 2007). In Brazil, large agricultural limitations are found in the flooded plains or wetlands (alluvial and hydromorphic soils), where the periodical floodings restrict the agricultural practice, except for rice crops, which are more adapted (Silva et al., 2007). Concerned with this fact and thinking of the possibility of maize being a good crop option for Brazilian wetlands, Embrapa Milho e Sorgo has developed, by means of a stratified phenotypic recurrent selection, a maize variety known as 'Saracura BRS-4154', which is capable of surviving, yielding and tolerating intermittent periods of soil flooding (Ferreira et al., 2007). This variety is currently in its $18^{\text {th }}$ annual selection cycle. Its ability to tolerate intermittent periods of flooding is due to the presence of different biochemical and physiological mechanisms, and also to root morphoanatomical modifications, such as the formation of aerenchyma and the modification of the vascular tissues (Ferreira et al., 2008; Pereira et al., 2008). Leaves of the 'Saracura' maize (BRS-4154) cultivated in a greenhouse with root flooding presented variations in the diameter of the vascular bundles as well as in the size and amount of stomata (Melo et al., 2004).

The objective of this work was to evaluate the effect of successive selection cycles on leaf plasticity of 'Saracura' maize under periodical flooding in field conditions.

\section{Materials and Methods}

The experiment was carried out from October 2007 to January 2008, under field conditions, at Embrapa Milho e Sorgo, Sete Lagoas, Minas Gerais state, Brazil
(Köppen climate classification Aw, savanna with dry winter, $732-\mathrm{m}$ altitude, $\left.19^{\circ} 28^{\prime} \mathrm{S}, 44^{\circ} 15^{\prime} \mathrm{W}\right)$. The maximum and minimum temperatures registered during the evaluation period were 30 and $18^{\circ} \mathrm{C}$ respectively. The average relative humidity was of $64.3 \%$, and the accumulated precipitation was of $852 \mathrm{~mm}$.

With the purpose of facilitating the flooding, the area was leveled and divided into lots. A randomized block design with three replicates was used. The experimental plots were composed of four 5-m-long rows with $0.9-\mathrm{m}$ spacing from each other. The distance between the plants in the plot line was of $0.2 \mathrm{~m}$, and the useful area corresponded to two central rows. Water from a nearby reservoir was used for flooding the lots and conducted by pumps to the experiment's location. The fertilization of the soil, classified as wetland fields' plain-relief phase Entisol with clayey texture ("Neossolo Flúvico Tb eutrófico típico, textura argilosa") (Santos et al., 2006), was performed according to the chemical analysis. Basic 5-20-20 + Zn fertilizer in doses of $400 \mathrm{~kg} \mathrm{ha}^{-1}$ were applied at sowing and after the germination of the caryopses, two top dressings with ammonium sulphate were carried out in doses of 20 grams per linear meter, the first at the stage of six leaves and the second at the stage of eight leaves. All phytosanitary treatments required by the crop were applied.

The flooding was initiated at the stage of six leaves (when the meristem of the plants is already above the ground surface) (Magalhães et al., 2007), with addition of a $20-\mathrm{cm}$ depth water layer three times a week, and ended at the physiological maturity of the plant. The genetic material used consisted of alternating cycles of selection of 'Saracura' BRS 4154 maize: C1, C3, C5, C7, C9, C11, C13, C15, C17 and C18, and one BR 107 variety as control, known for its susceptibility to flooding.

At flowering, the phase most susceptible to the stress caused by water excess (Zaidi et al., 2007), a sample of the medium third of a totally expanded leaf below the flag leaf from two plants of each replicate was randomly collected and fixed in formaldehyde, acetic acid, and 70\% ethanol solution (FAA 70) for 48 hours and then preserved in $70 \%$ ethanol. Transversal sections of the mesophyll and midrib were performed with Table microtome, and the paradermical sections were manually acquired from the adaxial and abaxial surfaces at the Laboratório de Anatomia Vegetal of Universidade Federal de Lavras. The transversal 
sections were clarified with 5\% sodium hypochlorite for $10 \mathrm{~min}$, rehydrated for $10 \mathrm{~min}$, stained with astrablau (7.5:2.5 safranine and astra blue solution) and mounted on slides with $50 \%$ glycerin. The paradermical sections were also clarified with $5 \%$ sodium hypochlorite for 10 min, rehydrated for $10 \mathrm{~min}$, stained with $2 \%$ safranine and mounted on slides with $50 \%$ glycerin.

The sections were photographed in an Olympus BX-60 photon microscope coupled to a digital camera. The parameters measured in the paradermic section of the adaxial and abaxial surfaces were: stomatal density; number of stomata per square millimeter; stomatal index, 100 (number of stomata per square millimeter/number of epidermis cells); polar diameter of the stoma; and stomatal functionality, polar diameter/equatorial diameter. The parameters evaluated for the midrib were: number of vascular bundles (NV); total number of metaxylem vessels in the vascular bundles; metaxylem vessel diameter in the midrib (VD); Carlquist's vulnerability index, VD/NV (Carlquist, 1975); phloem thickness in the midrib vascular bundles; medium diameter of the ten parenchyma cells; and sclerenchyma area. For the leaf blade, the following were measured: adaxial epidermis thickness, abaxial epidermis thickness, mesophyll thickness, adaxial cuticle thickness, phloem thickness of the vascular bundles, diameter of metaxylem vessels, distance between the vascular bundles, number of bulliform cells at every $2 \mathrm{~mm}$, and polar diameter of the bulliform cells. The anatomical evaluations of the leaf blades were performed in the region of the fourth vascular bundle, counting from the midrib toward the leaf border, where a higher uniformity in the thickness of the leaf blade was observed. Vascular bundles present in the largest midrib and in the fourth biggest vascular bundle after the central vein were used as standard for the vascular bundle evaluation.

The measurements were made using the UTHSCSA ImageTool (University of Texas, San Antonio, USA) image analysis program, and the calibrations were undertaken with a microscope ruler photographed in the same scale as the photomicrographies. The final data were determined by taking the average measurement of leaves from two plants of each replicate. In each leaf, five measurements of each anatomical trait were taken. For the statistical analysis of the results, analysis of variance (ANOVA) and the Scott-Knott test for the means comparison at 5\% probability were applied using Sisvar version 4.0 (Ferreira, 2000).

\section{Results and Discussion}

Modifications in the paradermic sections were observed both on the adaxial and abaxial surfaces of the leaf (Figure 1). The stomatal density on the adaxial surface was statistically higher in the $\mathrm{C} 17$ and C18 in comparison to the other cycles and the control (Table 1). The stomatal density of the $\mathrm{C} 18$ presented an increase of 45.2 and $41.9 \%$ on the adaxial surface compared to the BR 107 and the C1 respectively. The stomatal index on the adaxial surface was also higher in the last two cycles and smaller in the control. C18 presented an increase of $42.76 \%$ in comparison to the control, and of $30.4 \%$ in comparison to the C1. The adaxial stomatal functionality was higher in $\mathrm{C} 15$, C17, and C18 in comparison to the other cycles and
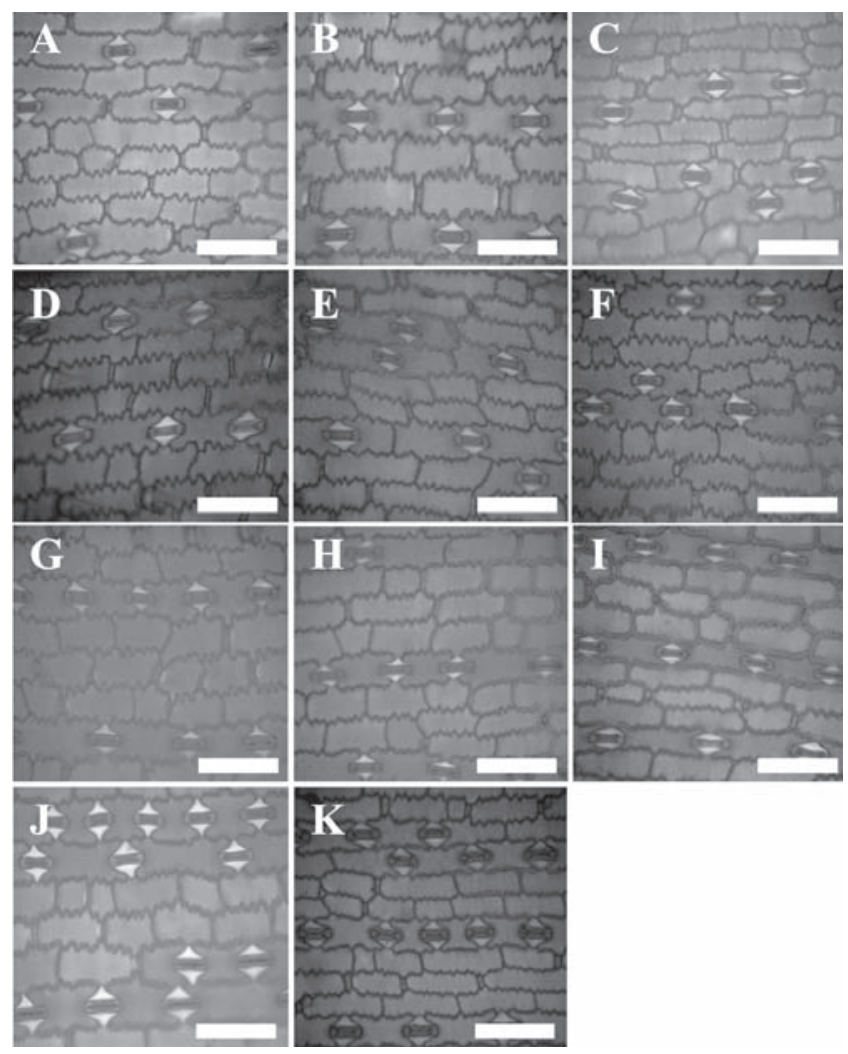

Figure 1. Presence of stomata on the adaxial surface throughout the selection cycles of 'Saracura' maize submitted to periodical flooding. A, BR 107 (control); B, C, D, E, F, G, H, I, J and K, cycles 1, 3, 5, 7, 9, 11, 13, 15, 17 and 18 respectively. $\mathrm{Bar}=100 \mu \mathrm{m}$. 
the control, which were not different from each other. C18 presented $29.4 \%$ more functionality than the control and 25.4\% more than $\mathrm{C} 1$. The polar diameter of the stoma from the adaxial surface was higher in C13, C15, C17 and C18 in comparison to the initial cycles and the control. On the abaxial surface, despite the fact that stomatal density had higher values than on the adaxial surface, no significant differences were detected among the treatments. The stomatal index of the abaxial surface presented difference and higher values in C9, C11, C15, C17 and C18. The cycle with the highest average (C9) presented a stomatal index $59.9 \%$ higher than that of the control and $26.4 \%$ higher than that of $\mathrm{C} 1$. There was no significant difference in the stomatal functionality of the abaxial surface. However, for stomatal polar diameter, the control together with $\mathrm{C} 1$ presented significantly lower values than the other selection cycles.

Stomata density can also vary in other types of abiotic stresses, such as drought, when a decrease in the stomata density occurs (Bergmann, 2004). The closing of the stomata is one of the most prominent responses to flooding, leading to a decrease in gas exchange (Nicolás et al., 2005) and consequently to a decrease in photosynthesis and in stoma conductance. However, an optimization promoted by an increase in the number of stomata can favor a greater intake of carbon dioxide gas, which diminishes the stomata resistance and facilitates the carbon assimilation process (Henrique et al., 2010). This probably occurred in the 'Saracura' maize, because there was an increase in the stomata number, both by area and by number of epidermis cells in the last selection cycles, which might benefit the gas exchange. Changes in the size of barley stomata were observed in studies of flooding (Yordanova et al., 2005). However, other authors did not observe changes in the amount and size of stomata in leguminous from flooded regions (Lotus corniculatus L. and Lotus glaber Mill.) (Striker et al., 2005), which shows that the stomata changes are not very clear in all of the species exposed to this kind of stress. Many studies have described that the ability of roots in absorbing water is affected by the lack of oxygen in flooded environments (Dell'Amico et al., 2001; Tournaire-Roux et al., 2003). Higher functionality in the last cycles can favor higher water use efficiency, because they can get carbon dioxide gas with a smaller area of stoma opening, thus avoiding greater loss of water. The same can be observed by the increase in the polar diameter in the last cycles, which is directly related to the stoma functionality. All these characteristics can favor a higher $\mathrm{CO}_{2}$ absorption, an important factor that can increase the quantity of internal carbon, which predisposes a higher energy production for the survival and growth of the crop in flooded areas. However, ecophysiological and biochemical studies should be carried out to support these suggestions, because in some species, including maize, an inhibition in the carboxylation can occur in flooded areas (Yordanova et al., 2005).

The number of vascular bundles increased throughout the selection cycles (Table 2). C3 and the control showed the lowest average, while C15 and C18 presented the highest average. There was an increase of 31.5\% in C18 in comparison to the control,

Table 1. Parameters measured on the paradermical sections of the adaxial and abaxial surfaces of leaves of 'Saracura' maize of successive selection cycles (C1 to $\mathrm{C} 18)$ submitted to intermittent flooding ${ }^{(1)}$.

\begin{tabular}{|c|c|c|c|c|c|c|c|c|}
\hline \multirow[t]{2}{*}{ Treatment } & \multicolumn{4}{|c|}{ Adaxial surface } & \multicolumn{4}{|c|}{ Abaxial surface } \\
\hline & SD & SI & $\mathrm{SF}$ & $\mathrm{SPD}(\mu \mathrm{m})$ & $\mathrm{SD}$ & SI & SF & $\mathrm{SPD}(\mu \mathrm{m})$ \\
\hline BR 107 & $59.81 b$ & $9.72 \mathrm{c}$ & $1.25 \mathrm{~b}$ & $43.18 b$ & $77.41 \mathrm{a}$ & $10.61 b$ & $1.18 \mathrm{a}$ & $41.83 b$ \\
\hline $\mathrm{C} 1$ & $63.33 b$ & $11.81 \mathrm{c}$ & $1.32 \mathrm{~b}$ & $42.94 b$ & $84.44 a$ & $13.04 \mathrm{~b}$ & $1.45 \mathrm{a}$ & $42.32 b$ \\
\hline C3 & $63.30 \mathrm{~b}$ & $11.53 \mathrm{c}$ & $1.30 \mathrm{~b}$ & $44.28 \mathrm{~b}$ & $91.48 \mathrm{a}$ & $13.70 \mathrm{~b}$ & $1.53 \mathrm{a}$ & $44.56 a$ \\
\hline $\mathrm{C} 5$ & $63.33 b$ & $11.81 \mathrm{c}$ & $1.42 \mathrm{~b}$ & $44.57 b$ & $84.44 a$ & $13.04 b$ & $1.51 \mathrm{a}$ & $45.83 a$ \\
\hline C7 & $70.37 b$ & $13.80 \mathrm{~b}$ & $1.38 \mathrm{~b}$ & $45.01 \mathrm{~b}$ & $87.96 a$ & $13.62 b$ & $1.60 \mathrm{a}$ & $45.76 \mathrm{a}$ \\
\hline C9 & $63.33 b$ & $12.13 \mathrm{c}$ & $1.42 \mathrm{~b}$ & $44.22 b$ & $105.55 \mathrm{a}$ & $17.73 \mathrm{a}$ & $1.42 \mathrm{a}$ & $46.07 \mathrm{a}$ \\
\hline C11 & $66.85 b$ & $12.71 \mathrm{c}$ & $1.50 \mathrm{~b}$ & $45.78 b$ & $109.07 \mathrm{a}$ & $16.13 \mathrm{a}$ & $1.55 \mathrm{a}$ & $46.44 a$ \\
\hline $\mathrm{C} 13$ & $77.41 b$ & $14.58 b$ & $1.45 \mathrm{~b}$ & $46.66 \mathrm{a}$ & $95.00 \mathrm{a}$ & $12.68 b$ & $1.49 \mathrm{a}$ & $46.63 a$ \\
\hline $\mathrm{C} 15$ & $77.41 b$ & $13.95 b$ & $1.74 \mathrm{a}$ & $48.02 \mathrm{a}$ & $95.00 \mathrm{a}$ & $14.87 \mathrm{a}$ & $1.58 \mathrm{a}$ & $46.52 \mathrm{a}$ \\
\hline $\mathrm{C} 17$ & $98.52 \mathrm{a}$ & $17.51 \mathrm{a}$ & $1.74 \mathrm{a}$ & $48.55 a$ & $98.54 \mathrm{a}$ & $17.18 \mathrm{a}$ & $1.56 \mathrm{a}$ & $46.12 \mathrm{a}$ \\
\hline C18 & $109.07 \mathrm{a}$ & $16.98 \mathrm{a}$ & $1.77 \mathrm{a}$ & $48.26 \mathrm{a}$ & $110.55 \mathrm{a}$ & $15.96 \mathrm{a}$ & $1.65 \mathrm{a}$ & $47.57 \mathrm{a}$ \\
\hline CV (\%) & 18.15 & 12.69 & 14.91 & 4.18 & 15.81 & 13.67 & 9.78 & 3.96 \\
\hline
\end{tabular}

${ }^{(1)}$ Means followed by equal letters within columns do not differ significantly by the Scott-Knott test, at 5\% probability. SD, stomatal density; SI, stomatal index; SF, stomatal functionality; SPD, stomatal polar diameter. 
and of $37 \%$ in comparison to C3. The total number of metaxylem vessels in the vascular bundles also increased throughout the cycles: C1, C3 and the control were statistically similar, with the lowest averages, and C13, C15, C17 and C18 presented the highest total number. $\mathrm{C} 1$ corresponded to $42 \%$ of the total number of metaxylem vessels in the vascular bundles of C18. Regarding the diameter of metaxylem vessels, it was observed that C1, C3, C5 and the control presented the highest average, and C13, C15, C17 and C18, the lowest average. The diameter of the metaxylem vessels of C18 decreased 37.9\% in comparison to C1 (Table 2, Figure $2 \mathrm{~A}$ to $\mathrm{C}$ ). The highest value of Carlquist's vulnerability index was found in the control, and C13, C15, C17 and C18 corresponded to the lowest index, being statistically similar to each other. Still regarding the midrib vascular bundles, an increase in the phloem thickness was observed starting on the fifth cycle. C18 showed an increase of $26.1 \%$ in comparison to the control and of $24.3 \%$ in comparison to C1 (Table 2, Figure $2 \mathrm{~A}$ to $\mathrm{C}$ ). There was no difference among the diameter of the parenchyma cells. For the sclerenchyma area in the midrib, a decrease was observed throughout the cycles. The greatest area was found in the control and in $\mathrm{C} 1$. From $\mathrm{C} 7$ to $\mathrm{C} 18$, no statistical difference was detected. The sclerenchyma area of C18 corresponded to $68 \%$ of the control's area and to $70.1 \%$ of cycle 1 's area.

The lack of oxygen in flooded areas can cause a decrease in water conductivity in plants (Dell'Amico et al., 2001). The low conductivity leads to the cavitation process, which can diminish the plant capacity in transporting water and fixing carbon (Mostajeran \& Rahimi-Eichi, 2008). When the species have higher quantity of vessels, there is a higher water flow and higher chances to avoid cavitation (Zimmermann, 1983). The diameter of metaxylem vessels is also an important factor in the water flow, because vessels with greater caliber are more prone to cavitation than vessels with smaller caliber (Vasellati et al., 2001). Therefore, the increase in the number of bundles and metaxylem vessels in the last selection cycles of 'Saracura' maize could be protecting the water system and possibly favoring the water absorption in the root, the flow and the distribution of water in the leaves. Such protection in the conducting system is shown by the smaller value of Carlquist's vulnerability index in C13, C15, C17 and $\mathrm{C} 18$ (Table 2). A smaller metaxylem vessel diameter in the last selection cycles can also avoid cavitation and embolism due to the increase in the number of water molecules in contact to xylem cell walls per water volume (Hacke \& Sperry, 2001).

An increase in the thickness of the phloem can be an important adaptation for the plants submitted to flooding. With the hypoxia, the transportation of photosynthates to the root is inhibited (Liao \& Lin, 2001), and, at the same time, lower energy production occurs due to the blockage of oxidative phosphorylation. Furthermore, the decrease of photosynthate flow to the root can cause accumulation of carbohydrates in the chloroplasts, which leads to inhibition of the photosynthesis and decrease of sugars (Liao \& Lin, 2001). The roots, as a response to the absence of sugar, deplete the carbohydrate reserves, which makes a

Table 2. Parameters measured midrib anatomical parameters from successive selection cycles (C1 to C18) of 'Saracura' maize submitted to intermittent flooding ${ }^{(1)}$.

\begin{tabular}{|c|c|c|c|c|c|c|c|}
\hline Treatment & $\mathrm{NV}$ & $\mathrm{TV}$ & $\mathrm{VD}(\mu \mathrm{m})$ & VI & $\mathrm{PL}(\mu \mathrm{m})$ & $\mathrm{PC}(\mu \mathrm{m})$ & $\mathrm{SC}\left(\mu \mathrm{m}^{2}\right)$ \\
\hline$\overline{\text { BR } 107}$ & $12.33 \mathrm{~d}$ & $7.17 \mathrm{c}$ & $74.55 \mathrm{a}$ & $10.67 \mathrm{a}$ & $53.62 b$ & $75.90 a$ & $35,027.67 \mathrm{a}$ \\
\hline $\mathrm{C} 1$ & $13.50 \mathrm{c}$ & $7.50 \mathrm{c}$ & $66.85 \mathrm{a}$ & $9.00 \mathrm{~b}$ & $54.91 \mathrm{~b}$ & $95.03 \mathrm{a}$ & $33,977.50 \mathrm{a}$ \\
\hline $\mathrm{C} 3$ & $11.33 \mathrm{~d}$ & $7.67 \mathrm{c}$ & $68.22 \mathrm{a}$ & $9.00 \mathrm{~b}$ & $60.78 \mathrm{~b}$ & $75.72 \mathrm{a}$ & $29,179.10 \mathrm{~b}$ \\
\hline $\mathrm{C} 5$ & $13.50 \mathrm{c}$ & $9.33 b$ & $65.83 \mathrm{a}$ & $7.33 \mathrm{c}$ & $65.09 \mathrm{a}$ & $90.47 \mathrm{a}$ & $29,988.61 \mathrm{~b}$ \\
\hline C7 & $13.17 \mathrm{c}$ & $10.33 b$ & $56.72 \mathrm{~b}$ & $5.67 \mathrm{~d}$ & $64.60 \mathrm{a}$ & 93.99a & $27,496.26 \mathrm{c}$ \\
\hline C9 & $14.50 \mathrm{~b}$ & $11.00 \mathrm{~b}$ & $53.88 \mathrm{~b}$ & $5.00 \mathrm{~d}$ & $65.67 \mathrm{a}$ & $99.10 \mathrm{a}$ & $26,759.92 \mathrm{c}$ \\
\hline C11 & $15.17 \mathrm{~b}$ & $11.17 \mathrm{~b}$ & $52.82 \mathrm{~b}$ & $4.67 \mathrm{~d}$ & $67.65 \mathrm{a}$ & $104.03 \mathrm{a}$ & $25,268.84 \mathrm{c}$ \\
\hline $\mathrm{C} 13$ & $15.33 \mathrm{~b}$ & $14.00 \mathrm{a}$ & $47.24 c$ & $3.33 \mathrm{e}$ & $66.75 \mathrm{a}$ & $102.91 \mathrm{a}$ & $26,113.09 \mathrm{c}$ \\
\hline C15 & $16.67 \mathrm{a}$ & $15.17 \mathrm{a}$ & $44.00 \mathrm{c}$ & $2.67 \mathrm{e}$ & $65.81 \mathrm{a}$ & $94.02 \mathrm{a}$ & $24,380.54 c$ \\
\hline $\mathrm{C} 17$ & $16.00 \mathrm{~b}$ & $15.17 \mathrm{a}$ & $46.24 c$ & $3.00 \mathrm{e}$ & $67.00 \mathrm{a}$ & $93.80 \mathrm{a}$ & $24,253.33 c$ \\
\hline $\mathrm{C} 18$ & $18.00 \mathrm{a}$ & $17.83 \mathrm{a}$ & $41.52 \mathrm{c}$ & $2.33 \mathrm{e}$ & $72.57 \mathrm{a}$ & $95.71 \mathrm{a}$ & $23,845.13 \mathrm{c}$ \\
\hline CV (\%) & 6.48 & 16.16 & 7.79 & 16.93 & 7.33 & 18.49 & 8.43 \\
\hline
\end{tabular}

${ }^{(1)}$ Means followed by equal letters within columns do not differ significantly by the Scott-Knott test at $5 \%$ probability level. NV, number of vascular bundles; TV, total number of metaxylem vessels in the vascular bundles; VD, metaxylem vessel diameter; VI, Carlquist's vulnerability index; PL, phloem thickness in the midrib vascular bundles; PC, diameter of the parenchyma cells; SC, sclerenchyma area. 
higher intake of photosynthates necessary (Liao \& Lin, 2001). The increase of the number of vascular bundles and the phloem thickness in the last selection cycles of 'Saracura' maize could increase the photosynthates transportation from the leaf to other parts of the plant, as well as avoid photosynthesis inhibition.

The diameter of the parenchyma cells can influence the intercellular spaces, increasing the area of gases, such as oxygen (Souza et al., 2009). Furthermore, the death of the biggest cells in the aerenchyma formation could originate larger spaces in the leaf. However, no increase in the diameter of such cells or formation of aerenchyma throughout the selection cycles was verified.

Several studies had shown the increase of sclerenchyma in response to low water availability (Bacelar et al., 2004), an alteration that is important for the plants to avoid water loss. The first cycles produced

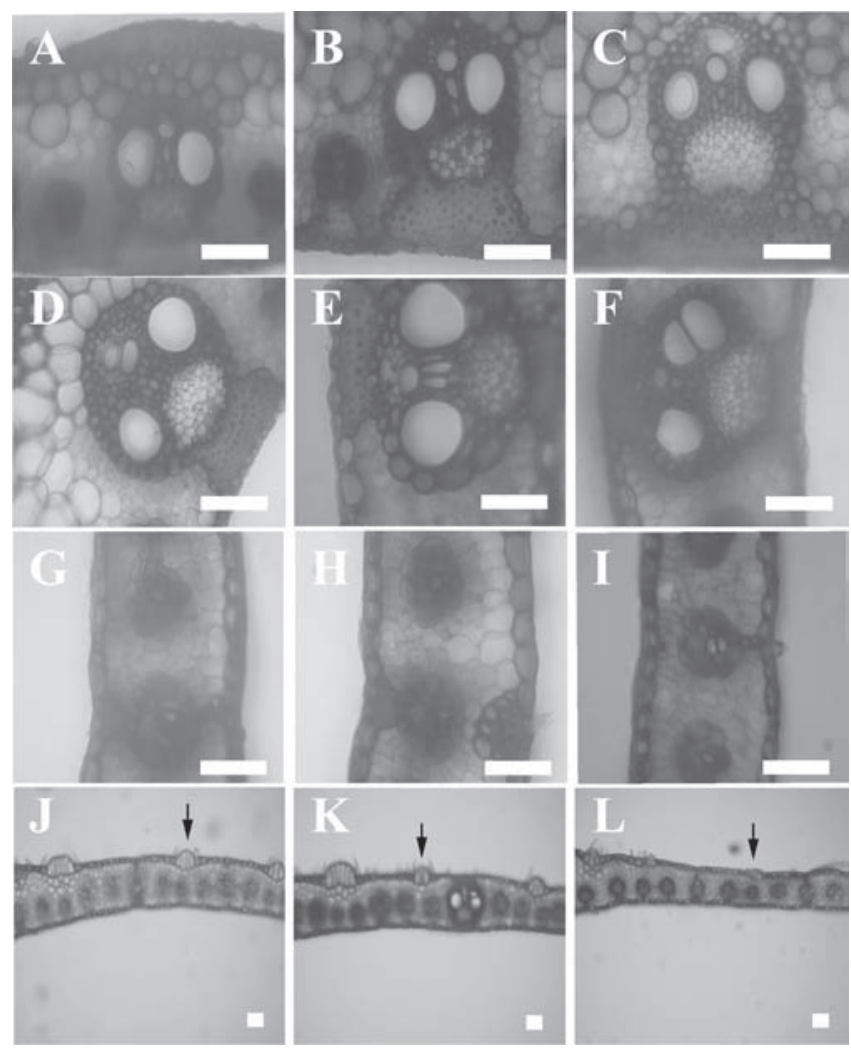

Figure 2. Anatomical characteristics of transversal sections of midrib and leaf blade. Control BR 107 (A, D, G, J); selection cycle 1 (B, E, H, K); selection cycle 18 (C, F, I, L). Midrib $(\mathrm{A}, \mathrm{B}, \mathrm{C})$ and leaf blade $(\mathrm{D}, \mathrm{E}, \mathrm{F})$ with vascular bundle detail, leaf blade evidencing epidermis $(G, H, I)$, showing the bulliform cells (J, K, L). Bar $=100 \mu \mathrm{m}$. higher quantity of this tissue, which shows a possible attempt to save water, since these cycles showed a more vulnerable vascular system than the last cycles. Lower investment in the sclerenchyma area occurred after C7. The reduction of sclerenchyma can lead to the production of other more important tissues, such as phloem, which facilitates the survival of the cycles of 'Saracura' maize in flooded environments.

Adaxial epidermis thickness and abaxial epidermis thickness significantly decreased throughout the selection cycles (Table 3 ). There was a decrease of $28.7 \%$ in the adaxial epidermis of $\mathrm{C} 18$ when compared to the control, and of $20.1 \%$ in comparison to $\mathrm{C} 1$ (Table 3, Figure $2 \mathrm{G}$ to I). The abaxial epidermis of $\mathrm{C} 18$, on the other hand, decreased $24.4 \%$ in comparison to the control and $15.9 \%$ in comparison to C1. No statistically significant differences were observed for the mesophyll thickness. Regarding the cuticle, a significant decrease started to show in the fifth cycle, and C5, C7, C9, C11, C13, C15, C17 and C18 were all similar. C18 cuticle decreased approximately $34.5 \%$ in comparison to the control and to C1. Conversely, phloem thickness of the vascular bundles in the leaf blade presented statistically higher values from C11 to C18. The last cycle resulted in an increase of $25.72 \%$ in comparison to the control, and of $19.67 \%$ in comparison to C1 (Table 3, Figure 2 D to F). A decrease in diameter of metaxylem vessels was observed throughout the selection cycles (Figure 2 D, E and $F$ ). The greatest metaxylem diameter was found in the control $(66.50 \mu \mathrm{m})$, which was statistically similar to that of $\mathrm{C} 1, \mathrm{C} 3, \mathrm{C} 5$ and $\mathrm{C} 7, \mathrm{C} 18$, together with C9, C11, C13, C15 and C17, resulted in the smallest diameter. C1 and C3 as well as the sensitive variety BR 107 presented the biggest distances between the vascular bundles, and were similar to each other. From $\mathrm{C} 5$ to $\mathrm{C} 18$ there was a decrease in this distance; however, the cycles did not differ from each other. C18 in comparison to BR 107 and C1 presented a decrease of 15.49 and $12.14 \%$, respectively. The number of bulliform cells of the control was statistically similar to that of C1, C3 and C5. Starting in C7 to C18, the averages were equal and smaller. C18 had a decrease of $31.4 \%$ in comparison to that of the control, and of $30 \%$ in comparison to C1. Diameter of the bulliform cells also decreased throughout the selection cycles (Table 3, Figure $2 \mathrm{~J}$ to $\mathrm{L}$ ). Control and C1, C3, C7 and C9 were statistically similar to each other, and corresponded to the highest averages. 
Table 3. Leaf blade anatomical parameters $(\mu \mathrm{m})$ from successive selection cycles ( $\mathrm{C} 1$ to $\mathrm{C} 18)$ of 'Saracura' maize submitted to intermittent flooding ${ }^{(1)}$.

\begin{tabular}{|c|c|c|c|c|c|c|c|c|c|}
\hline Treatment & DET & BET & MPT & DCT & PHT & DMV & DVB & $\mathrm{NBC}$ & PDB \\
\hline BR 107 & $26.96 a$ & $24.15 a$ & $181.45 \mathrm{a}$ & $14.57 \mathrm{a}$ & $48.94 b$ & $66.50 \mathrm{a}$ & $180.29 a$ & $8.50 \mathrm{a}$ & $68.95 a$ \\
\hline $\mathrm{C} 1$ & $24.57 \mathrm{a}$ & $22.86 a$ & $182.28 \mathrm{a}$ & $14.55 \mathrm{a}$ & $52.93 b$ & $65.95 \mathrm{a}$ & $173.41 \mathrm{a}$ & $8.33 \mathrm{a}$ & $73.35 \mathrm{a}$ \\
\hline C3 & $27.28 \mathrm{a}$ & $22.55 \mathrm{a}$ & $177.73 \mathrm{a}$ & $14.12 \mathrm{a}$ & $43.74 b$ & $64.83 a$ & $172.86 \mathrm{a}$ & $8.50 \mathrm{a}$ & $66.90 \mathrm{a}$ \\
\hline C5 & $27.02 \mathrm{a}$ & $24.30 \mathrm{a}$ & $178.29 \mathrm{a}$ & $11.44 b$ & $50.79 b$ & $66.28 \mathrm{a}$ & $162.35 b$ & $8.33 \mathrm{a}$ & $55.85 \mathrm{~b}$ \\
\hline $\mathrm{C} 7$ & $27.26 \mathrm{a}$ & $22.00 \mathrm{a}$ & $164.77 \mathrm{a}$ & $11.64 b$ & $49.36 b$ & $70.11 \mathrm{a}$ & $153.30 \mathrm{~b}$ & $6.67 \mathrm{~b}$ & $61.70 \mathrm{a}$ \\
\hline C9 & $23.82 \mathrm{a}$ & $22.84 \mathrm{a}$ & $174.15 \mathrm{a}$ & $11.95 b$ & $49.73 b$ & $61.85 b$ & $156.20 \mathrm{~b}$ & $7.33 b$ & $61.47 \mathrm{a}$ \\
\hline C11 & $23.61 \mathrm{a}$ & $20.76 b$ & $167.66 \mathrm{a}$ & $10.78 b$ & $55.92 \mathrm{a}$ & $59.67 \mathrm{~b}$ & $152.38 b$ & $7.33 b$ & $53.36 \mathrm{~b}$ \\
\hline C13 & $20.69 b$ & $20.28 b$ & $170.18 \mathrm{a}$ & $10.75 b$ & $57.35 \mathrm{a}$ & $62.43 b$ & $155.22 b$ & $5.67 \mathrm{~b}$ & $52.41 b$ \\
\hline C 15 & $20.82 b$ & $21.42 b$ & $171.37 \mathrm{a}$ & $10.66 \mathrm{~b}$ & $61.65 a$ & $59.89 b$ & $157.33 b$ & $6.33 b$ & $49.72 b$ \\
\hline C17 & $20.77 b$ & $19.69 b$ & $175.26 \mathrm{a}$ & $10.24 b$ & $66.20 \mathrm{a}$ & $56.80 \mathrm{~b}$ & $159.94 b$ & $6.17 \mathrm{~b}$ & $57.66 \mathrm{~b}$ \\
\hline C18 & $19.62 b$ & $19.22 \mathrm{~b}$ & $156.61 \mathrm{a}$ & $9.53 \mathrm{~b}$ & $65.89 a$ & $54.05 \mathrm{~b}$ & $152.36 \mathrm{~b}$ & $5.83 \mathrm{~b}$ & $49.68 b$ \\
\hline $\mathrm{CV}(\%)$ & 9.18 & 7.96 & 4.52 & 9.69 & 12.27 & 06.38 & 3.01 & 14.38 & 10.31 \\
\hline
\end{tabular}

${ }^{(1)}$ Means followed by equal letters within columns do not differ significantly by the Scott-Knott test at $5 \%$ probability level. DET, adaxial epidermis thickness; BET, abaxial epidermis thickness; MPT, mesophyllum thickness; DCT, adaxial cuticle thickness; PHT, phloem thickness in the vascular bundles; DMV, diameter of metaxylem vessels; DVB, distance between the vascular bundles; NBC, number of bulliform cells at every $2 \mathrm{~mm}$; PDB, polar diameter of the bulliform cells.

Although flooding may lead to water deficit (Dell'Amico et al., 2001; Tournaire-Roux et al., 2003), the last selection cycles showed thinner epidermis and cuticle. This modification may be due to low requirement of those selection cycles in retaining water, since they are probably more adapted and therefore establish a greater water conductivity in the flooded environment.

With the leaves completely immersed in water, the mesophyll can modify itself and become thinner, therefore diminishing loss of water and increasing gas diffusion (Mommer et al., 2007). Stoyanova etal. (2005) did not find differences in the mesophyll of the maize cultivar Knezha 6112L submitted to flooding. Even though no significant differences in the mesophyll of the selection cycles of 'Saracura' maize were observed in the present work, Melo et al. (2004) found significant differences in C14 of the same variety when submitted to flooding in a greenhouse.

A greater number of bulliform cells with bigger polar diameter in the initial cycles is possibly related to leaf curling, which leads to a decrease in the transpiration surface area (Alvarez et al., 2008). This fact is important at the initial cycles, because they are more sensitive to flooding. The bulliform cells are motor cells that promote folding and curling of the leaves. The last selection cycles are probably more physiologically adapted to the periodical flooding, allowing the leaf to uncurl with increase in the photosynthetic surface without increase in transpiration.

The selection cycles of 'Saracura' maize under flooding presented characteristics that are typical of $\mathrm{C} 4$ plants, but with more intensified stomatal characters to increase carbon dioxide gas concentration and to use water more efficiently, as well as higher capacity of the conducting tissues (both phloem and xylem). It was observed that from C5 to C18 there was a smaller distance between the vascular bundles and, as a consequence, smaller internerval space and higher venal density (Roth-Nebelsick et al., 2001). The distance between vascular bundles can be related to the more efficient transportation and distribution of carbohydrates and water to the mesophyll cells. Studies on parallel vascular bundles in grasses showed that C4-type species present smaller distance between the vascular bundles than C3 type (Ueno et al., 2006). Such characteristic, present in C4-type plants, conveys higher ability in photosynthate translocation and higher water distribution in environments with water restriction and high temperatures (Sage, 2004). Just as a greater phloem thickness could increase the photosynthetic flow, a reduced space between the vascular bundles in the selection cycles of 'Saracura' maize could also increase this flow, because it would promote higher photosynthate distribution (Roth-Nebelsick et al., 2001) in addition to a higher water distribution.

\section{Conclusion}

The successive selection cycles of 'Saracura' maize result in modifications in leaf anatomy that are potentially favorable to its tolerance to the periodical soil flooding. 


\section{Acknowledgements}

To Coordenação de Aperfeiçoamento de Pessoal de Nível Superior, for the scholarship; to Embrapa Milho e Sorgo and to the Laboratório de Anatomia Vegetal of Universidade Federal de Lavras, for the support for the accomplishment of this research.

\section{References}

ALVAREZ, J.M.; ROCHA, J.F.; MACHADO, S.R. Bulliform cells in Loudetiopsis chrysothrix (Nees) Conert and Tristachya leiostachya Nees (Poaceae): structure in relation to function. Brazilian Archives of Biology and Technology, v.51, p.113-119, 2008.

BACELAR, E.A.; CORREIA, C.M.; MOUTINHO-PEREIRA, J.M.; GONÇALVES, B.C.; LOPES, J.I.; TORRES-PEREIRA, J.M.G. Sclerophylly and leaf anatomical traits of five field-grown olive cultivars growing under drought conditions. Tree Physiology, v.24, p.233-239, 2004.

BERGMANN, D.C. Integrating signals in stomatal development. Current Opinion in Plant Biology, v.7, p.26-32, 2004.

BRAGINA, T.V.; PONOMAREVA, Y.V.; DROZDOVA, I.S.; GRINIEVA, G.M. Photosynthesis and dark respiration in leaves of different ages of partly flooded maize seedlings. Russian Journal of Plant Physiology, v.51, p.342-347, 2004.

CARLQUIST, S. Ecological strategies of xylem evolution. Berkeley: University of California Press, 1975. 259p.

DAT, J.F.; CAPELLI, N.; FLOZER, H.; BOURGEADE, P.; BADOT, M. Sensing and signalling during plant flooding. Plant Physiology Biochemistry, v.42, p.273-282, 2004.

DELL'AMICO, J.; TORRECILLAS, A.; RODRIGUEZ, P.; MORALES, D.; SÁNCHEZ-BLANCO, J. Differences in the effects of flooding the soil early and late in the photoperiod on the water relations of pot-grown tomato plants. Plant Science, v.160, p.481-487, 2001.

FERREIRA, D.F. Análises estatísticas por meio do Sisvar para Windows versão 4.0. In: REUNIÃO ANUAL DA REGIÃO BRASILEIRA DA SOCIEDADE INTERNACIONAL DE BIOMETRIA, 45., 2000, São Carlos. Anais. São Carlos: UFSCar, 2000. p.255-258.

FERREIRA， J.L.; COELHO, C.H.M.; MAGALHÃES, P.C.; GAMA, E.E.G. e; BORÉM, A. Genetic variability and morphological modifications in flooding tolerance in maize, variety BRS-4154. Crop Breeding and Applied Biotechnology, v.7, p.314-320, 2007.

FERREIRA, J.L.; MAGALHÃES, P.C.; BORÉM, A. Evaluation of three physiologic characteristics in four cycles of selection in maize cultivar BRS-4154 under tolerance to waterlogging of the soil. Ciência e Agrotecnologia, v.32, p.1719-1723, 2008.

HACKE, U.G.; SPERRY, J.S. Functional and ecological xylem anatomy. Perspectives in Plant Ecology, Evolution and Systematics, v.4, p.97-115, 2001.
HENRIQUE, P. de C.; ALVES, J.D.; GOULART, P. de F.P.; DEUNER, S.; SILVEIRA, N.M.; ZANANDREA, I.; CASTRO, E.M. de. Características fisiológicas e anatômicas de plantas de sibipiruna submetidas à hipoxia. Ciência Rural, v.40, p.70-76, 2010.

HUBER, H.; JACOBS, E.; VISSER, E.J.W. Variation in flooding-induced morphological traits in natural populations of white clover (Trifolium repens) and their effects on plant performance during soil flooding. Annals of Botany, v.103, p.377-386, 2009.

LIAO, C.T.; LIN, C.H. Physiological adaptation of crop plants to flooding stress. Proceedings of the National Science Council, v.25, p.148-157, 2001

MAGALHÃES, P.C.; FERRER, J.L.R.; ALVES, J.D.; VASCONSELLOS, C.A.; CANTÃO, F.R. de O. Influência do cálcio na tolerância do milho "Saracura" BRS-4154 ao encharcamento do solo. Revista Brasileira de Milho e Sorgo, v.6, p.40-49, 2007.

MELO, H.C.; CASTRO, E.M.; ROMERO, J.L.; ALVES, J.D.; FRIES, D.D.; MELO, L.A.; MAGALHÃES, P.C. Influência da aplicação do cálcio e alagamento do solo sobre características anatômicas das folhas de milho (Zea mays L.) "Saracura" BRS-4154. Revista Brasileira de Milho e Sorgo, v.3, p.333-342, 2004.

MOMMER, L.; WOLTERS-ARTS, M.; ANDERSEN, C.; VISSER, E.J.W.; PEDERSON, O. Submergence-induced leaf acclimation in terrestrial species varying in flooding tolerance. New Physiologist, v.176, p.337-345, 2007.

MOSTAJERAN, A.; RAHIMI-EICHI, V. Drought stress effects on root anatomical characteristics of rice cultivars (Oryza sativa L.). Pakistan Journal of Biological Sciences, v.11, p.2173-2183, 2008.

NAVAS, M.-L.; GARNIER, E. Plasticity of whole plant and leaf traits in Rubia peregrina in response to light, nutrient and water availability. Acta Oecologica, v.23, p.375-383, 2002.

NICOLÁS, E.; TORRECILLAS, A.; DELL'AMICO, J.; ALARCÓN, J. The effect of short-term flooding on the sap flow, gas exchange and hydraulic conductivity of young apricot trees. Trees, v.19, p.51-57, 2005.

PEREIRA, F.J.; CASTRO, E.M. de; SOUZA, T.C. de; MAGALHÃES, P.C. Evolution of the root anatomy of 'Saracura' maize in successive selection cycles. Pesquisa Agropecuária Brasileira, v.43, p.1649-1656, 2008.

ROTH-NEBELSICK, A.; UHL, D.; MOSBRUGGER, V.; KERP, $\mathrm{H}$. Evolution and function of leaf venation architecture: a review. Annals of Botany, v.87, p.553-566, 2001.

SAGE, R.F. The evolution of $\mathrm{C}_{4}$ photosynthesis. New Phytologist, v.161, p.341-370, 2004.

SAIRAM, R.K.; KUMUTHA, D.; EZHILMATHI, K.; DESHMUKH, P.S.; SRIVASTAVA, G.C. Physiology and biochemistry of waterlogging tolerance in plants. Biologia Plantarum, v.52, p.401-412, 2008.

SANTOS, H.G. dos; JACOMINE, P.K.T.; ANJOS, L.H.C. dos; OLIVEIRA, V.A. de; OLIVEIRA, J.B. de; COELHO, M.R.; LUMBRERAS, J.F.; CUNHA, T.J.F. (Ed.). Sistema brasileiro 
de classificação de solos. 2.ed. Rio de Janeiro: Embrapa Solos, 2006. 306p.

SILVA, S.D. dos A. e; SERENO, M.J.C. de M.; SILVA, C.F.L. e; OLIVEIRA, A.C. de; BARBOSA NETO, J.F. Inheritance of tolerance to flooded soils in maize. Crop Breeding and Applied Biotechnology, v.7, p.165-172, 2007.

SOUZA, T.C. de; CASTRO, E.M. de; PEREIRA, F.J.; PARENTONI, S.N.; MAGALHÃES, P.C. Morpho-anatomical characterization of root in recurrent selection cycles for flood tolerance of maize (Zea mays L.). Plant Soil and Environment, v.55, p.504-510, 2009.

STOYANOVA, D.; TCHAKALOVA, E.; YORDANOV, L. Influence of different soil moisture on anatomy of maize leaves and ultrastructure of chloroplasts. Bulgarian Journal of Plant Physiology, v.28, p.11-20, 2002.

STRIKER, G.G.; INSAUSTI, P.; GRIMOLDI, A.A.; PLOSCHUK, E.E.; VASELLATI, V. Physiological and anatomical basis of differential tolerance to soil flooding of Lotus corniculatus L. and Lotus glaber Mill. Plant and Soil, v.276, p.301-311, 2005.

TOURNAIRE-ROUX, C.; SUFKA, M.; JAVOT, H.; GOUT, E.; GERBEAU, P.; LUU, D.-T.; BLIGNY, R.; MAUREL, C. Cytosolic
$\mathrm{pH}$ regulates root water transport during anoxic stress through gating of aquaporins. Nature, v.425, p.393-397, 2003.

UENO, O.; KAWANO, Y.; WAKAYAMA, M.; TAKEDA, T. Leaf vascular systems in $\mathrm{C}_{3}$ and $\mathrm{C}_{4}$ grasses: a two-dimensional analysis. Annals of Botany, v.97, p.611-621, 2006.

VASELLATI, V.; OESTERHELDS, M.; MEDAN, D.; LORETI, J. Effects of flooding and drought on the Anatomy of Paspalum dilatatum. Annals of Botany, v.88, p.355-360, 2001.

VOESENEK, L.A.C.J.; COLMER, T.D.; PIERIK, R.; MILLENAAR, F.F.; PEETERS, A.J.M. How plants cope with complete submergence. New Physiologist, v.170, p.213-226, 2006.

YORDANOVA, R.Y.; UZUNOVA, A.; POPOVA, L.P. Effects of short-term soil flooding on stomata behaviour and leaf gas exchange in barley plants. Biologia Plantarum, v.49, p.317-319, 2005.

ZAIDI, P.H.; MANISELVAN, P.; YADAV, P.; SINGH, A.K.; SULTANA, R.; DUREJA, P.; SINGH, R.P.; SRINIVASAN, G. Stress-adaptive changes in tropical maize (Zea mays L.) under excessive soil moisture stress. Maydica, v.52, p.159-171, 2007.

ZIMMERMANN, M.H. Xylem structure and the ascent of sap. Berlim: Springer-Verlag, 1983. 143p. (Springer series in wood science, 1).

Received on October 20, 2009 and accepted on November 30, 2009 